\title{
Communication of Scientific and Technological Systems with Regional Innovative Processes
}

\author{
Illia Morhachov \\ Department of Public Administration, \\ Management and Marketing Volodymyr \\ Dahl East Ukrainian National \\ University, \\ Severodonetsk, Ukraine \\ morgachov.ilya@gmail.com, \\ http://orcid.org/0000-0002-4347-3153 \\ Natalia Tkachenko \\ Department of Public Administration, \\ Management and Marketing Volodymyr \\ Dahl East Ukrainian National \\ University, \\ Severodonetsk, Ukraine \\ nataly_tkachenko@email.ua
}

\author{
Iryna Buzko \\ Department of International Economy \\ and Tourism Volodymyr Dahl East \\ Ukrainian National University, \\ Severodonetsk, Ukraine \\ buzko2006@gmail.com
}

\author{
Ievgen Ovcharenko \\ Department of Public Administration, \\ Management and Marketing Volodymyr \\ Dahl East Ukrainian National \\ University, \\ Severodonetsk, Ukraine \\ evvoukr@gmail.com, \\ http://orcid.org/0000-0001-5267-5067
}

\begin{abstract}
The aim of the work is to clarify the interconnection of the regional concentration of innovation activity of economic entities with the regional concentration of scientific and technical systems in Ukraine. The scientific and technical systems of Ukraine are the infrastructure of innovation and investment activity of its industrial enterprises. The results of the correlation analysis allowed on the macro level to reveal the interconnection of the innovation activity of industrial enterprises in Ukraine with its scientific and technical systems. While the meso-use of the method of comparing regional structures by calculating deviations did not allow to reveal of the significant link between the regional concentration of innovation activity and the regional concentration of all types of scientific and technical systems. The relevant relationship was found only with organizations on the sphere of engineering. In addition, a higher level of interconnection of innovation activities of industrial enterprises and organizations on the sphere of engineering was revealed and by the results of correlation analysis at the macro level. Clarification of the higher role of organizations of the sphere of engineering in the innovation activity of industrial enterprises in Ukraine allows us to revise and clarify priorities regarding the objects of influence in the state regulation in the direction.
\end{abstract}

Keywords- regional concentration, scientific and technical system, scientific organizations, organizations of the sphere of engineering, innovative activity

\section{INTRODUCTION}

The scientific and technical systems of Ukraine are part of the infrastructure of the innovation activity of its industrial enterprises. Therefore there of the innovation activity of the latter's should be connection with the results of the respective systems. Studies of such interconnections are relevant, since they allow to improve the infrastructure support of regional innovation processes. The actual quantitative analysis of the nature of the relevant influence is actual, which makes it possible to do evaluate of objectively.
All innovations require investment, so innovation activity should be correlated with investment in the long run, taking into account a certain "delay". That is, investments are initially made, and then, eventually, one can observe the results of the innovation activity, which are caused by the corresponding investments. The investment activity of enterprises should be correlated with the activity of organizations on the sphere of engineering, since almost all projects require the participation of these organizations. A prerequisite for innovation activity may also be the scientific activity of scientific organizations. Therefore, in the long run, there should also be a correlation, but in this case too, one should take into account the "delay".

In addition, scientific work of scientific organizations is often academic and fundamental in nature, so their transformation into any innovation can occur for a long time. This logical relationship manifests itself at the macro level. On the basis of further research at the regional level, the relevant issues are the quantitative influence of these factors on the regional concentration of scientific and technical systems and innovation activity of industrial enterprises.

In our study, we will focus on the hypothesis that, in the context of the relationship on the macro level between the innovation activity of industrial enterprises and the scientific and technical systems, the regional concentration of innovation activity of enterprises in Ukraine has no significant analogy with the regional concentration of all types of scientific and technical systems. To a greater extent, the relevant analogy can be traced the regional structure of the organizations of the sphere of engineering with of the regional structure innovative activity of enterprises.

The analysis of recent research and publications in the direction of innovation and scientific and technical activities $[1-5,7,9]$ allows us to determine the presence 
of deep developments in the subject. Despite the significant scientific achievements in this area of study, the hypothesis of linking the regional concentration of innovation activity of enterprises and scientific and technical systems in Ukraine still has reserves for deepening and clarification.

\section{OBJECTIVE}

The aim of the work is to clarify the interconnection of the regional concentration of innovation activity of economic entities with the regional concentration of scientific and technical systems in Ukraine. As additional tasks, we consider approbation of the author's approach to the study of causal relationships of scientific and technical systems based on regional differences.

\section{Methodology}

The results of the study were obtained using two main methods. The first is a correlation analysis used to determine the strength of communication at the macro level of the indicators of innovation activity of enterprises in Ukraine and its scientific and technical systems. The second is the comparison of the regional structure of these indicators. The method is described in detail in [6]. According to this method, it is possible to draw conclusions on the relationship between the investigated processes when the similarity of the regional structure of indicators that characterize these processes. Quantitative assessment was made by determining the total deviation by the of share for each region of the country. Such total deviations in terms of indicators were compared among themselves. If the corresponding total deviation was not exceed the $30 \%$ mark, the author subjectively to allowed the possibility to state the similarity of regional structures.

The use of correlation analysis requires by the increase of the studied time period, but at to use the method of comparisons regional structures - the opposite. For the study of regional processes, the author justified the use of these two methods simultaneously, since they complement and neutralize each other's defects.

Statistical information on the innovation activity of enterprises in Ukraine was obtained from open sources of the State Statistics Service of Ukraine on [8]. For receiving data on the indicators of scientific organizations in the country was using at the same sources. Information on organizations on the sphere of engineering was obtained according to the answers of the State Statistics Service of Ukraine to the author's requests.

\section{RESULTS}

As the main types of scientific and technical systems operating in Ukraine, we consider the following: higher educational establishments, scientific organizations, organizations of the sphere of engineering. If the main type of activity of higher education institutions is to study students', then it is possible to exclude directly influence these organizations from on the innovative activity of enterprises. However, higher education institutions in Ukraine are also performers of scientific works, therefore, in this part they can be attributed to scientific organizations and to investigate the direct impact of such works on the innovation activity of other business entities.

Before reaching the regional level, let's pay attention to the dynamics of the main indicators relevant to our research at the national level (Fig. 1, Fig. 2).

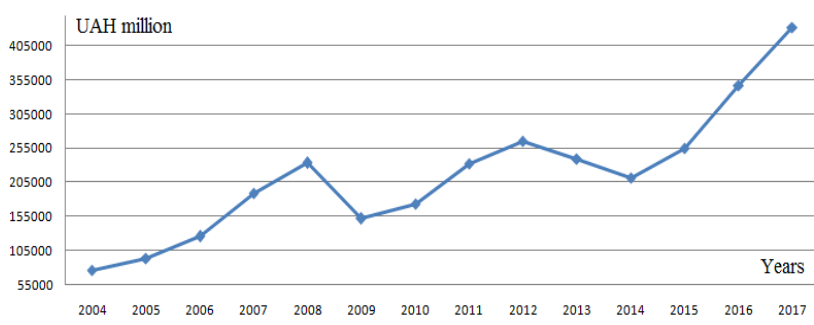

Fig. 1. Dynamics of investments of enterprises in Ukraine in actual prices

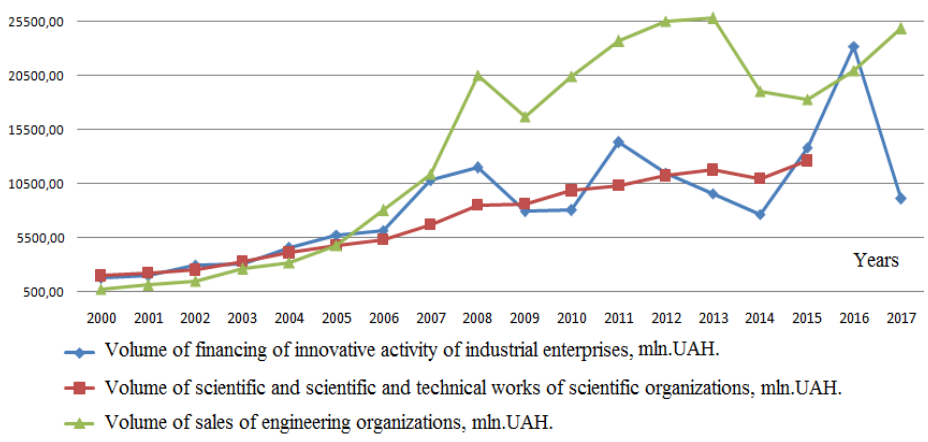

Fig. 2. Dynamics of financing of innovative activity of industrial enterprises and volumes of works of scientific and technical systems in Ukraine in actual prices

Consideration of the fig. 1 and 2 does not allow us to visually detect a $100 \%$ correlation between the investigated indicators, but certain compliance can be traced, for example, peaks in 2009 and 2004. In addition, on the fig. 1 and 2 was not covered the entire list of indicators of innovation activities of economic entities and factors related to the scientific and technical systems.

For the convenience of a quantitative study, a list of relevant indicators will be selected, as quantified by the State Statistics Service of Ukraine: 1) the number of industrial enterprises engaged in innovation activities; 2) the amount of financing of innovative activity of industrial enterprises; 3 ) the number of new technological processes introduced; 4) the number of industrial enterprises that implemented innovative products; 5) the value of the innovation products sold by the industrial enterprises; 6 ) the value of sales of innovative products by industrial enterprises outside Ukraine.

Determination of correlation coefficients on these indicators and results of scientific and technical systems is presented in Table 1. Calculations made by the authors.

Negative values of these coefficients (Table 1.) should be considered as the result of the absence of a significant relationship between the investigated indicators in the period under consideration. One of the reasons for not detecting a significant link may be the insignificant period of time for which the analysis was performed. 
Consideration of Table 1 allows to establish the existence of a certain connection at the macro level of innovation activity of economic entities in Ukraine with indicators of its scientific and technical of systems.

TABLE I. DETERMINATION OF THE STRENGTH OF COMMUNICATION RESULTS ACTIVITIES OF DOMESTIC SCIENTIFIC AND TECHNICAL SYSTEMS WITH INDICATORS CHARACTERIZING THE INNOVATIVE ACTIVITY OF INDUSTRIAL ENTERPRISES

\begin{tabular}{|l|c|c|c|c|c|c|}
\hline \multirow{2}{*}{ Indicator } & \multicolumn{5}{|c|}{$\begin{array}{l}\text { The value of the correlation coefficient } \\
\text { on the indices of innovative activity of } \\
\text { industrial enterprises }\end{array}$} \\
\cline { 2 - 8 } & $\mathbf{1}$ & $\mathbf{2}$ & $\mathbf{3}$ & $\mathbf{4}$ & $\mathbf{5}$ & $\mathbf{6}$ \\
\hline $\begin{array}{l}\text { 1. The volume of scientific } \\
\text { works performed by scientific } \\
\text { organizations, UAH. }\end{array}$ & 0.31 & 0.86 & 0.46 & -0.77 & 0.70 & 0.61 \\
\hline $\begin{array}{l}\text { 2. Number of scientific works } \\
\text { performed by scientific } \\
\text { organizations, units. }\end{array}$ & -0.30 & -0.24 & 0.11 & 0.24 & 0.13 & 0.24 \\
\hline $\begin{array}{l}\text { 2.1. among them the creation of } \\
\text { new types of technology }\end{array}$ & -0.16 & -0.19 & -0.14 & 0.30 & 0.31 & 0.43 \\
\hline $\begin{array}{l}2.2 \text { Of these, works that was } \\
\text { used inventions }\end{array}$ & 0.25 & 0.36 & 0.02 & 0.00 & 0.72 & 0.67 \\
\hline $\begin{array}{l}3 . \quad \text { Number of printed works, } \\
\text { units. }\end{array}$ & 0.60 & 0.74 & 0.57 & -0.42 & 0.69 & 0.53 \\
\hline $\begin{array}{l}4 . \quad \text { Volume of works by the } \\
\text { organizations of the sphere of } \\
\text { engineering, UAH. }\end{array}$ & 0.06 & 0.85 & 0.51 & -0.65 & 0.81 & 0.70 \\
\hline $\begin{array}{l}\text { 5. The volume of financing of } \\
\text { innovative activity of industrial } \\
\text { enterprises, UAH.* }\end{array}$ & - & - & 0.74 & 0.19 & 0.83 & 0.40 \\
\hline
\end{tabular}

*Notes: The volume of financing of innovation activity of industrial enterprises is not a result of activity of scientific and technical systems.

In particular, the value of the coefficients of correlation exceeds the value of " 0.7 " in the following pairs of indicators: the amount of financing innovative activity of industrial enterprises and the amount of scientific works performed by scientific organizations, as well as the first and volumes works of the organizations of the sphere of engineering; the volumes of the realized innovation products by industrial enterprises and the volumes of scientific works performed by scientific organizations, as well as the volumes of the realized innovation products by industrial enterprises and the volumes of works by the organizations of the sphere of engineering. Moreover, according to the indicator: "The volume of works by the organizations of the sphere of engineering" - you can state the higher values of the corresponding correlation coefficients.

Taking as a basis the mutual influence on each other of scientific and technical systems and innovation activity of industrial enterprises at the macro level, one can consider the hypothesis concerning the influence of the regional concentration of such activity in Ukraine on the regional concentration scientific and technical of systems. To confirm or refute this hypothesis is possible by comparing the regional structure of the indicators characterizing the results and factors of the activity of scientific and technical systems in Ukraine and the indicators characterizing the innovative activity of business entities in the regions of the country.

The average structure of the results the scientific and technical systems by regions Ukraine during 2000 - 2017 is shown in Table. 2. Calculations made by the authors.
In the table 2 the notation is taken:

1 - the volume of scientific works performed in value measure;

2 - the volume of works by the organizations of the sphere of engineering in value measure;

3 - number of performed scientific and scientific and technical works;

4 - the number of printed works;

5 - the number of received security documents on intellectual property rights.

TABLE II. THE AVERAGE STRUCTURE OF RESULTS OF THE DOMESTIC SCIENTIFIC AND TECHNICAL SYSTEMS BY REGIONS DURING 2000 - 2017 YEARS

\begin{tabular}{|l|l|l|l|l|l|}
\hline \multirow{2}{*}{\multicolumn{1}{|c|}{ Regions }} & \multicolumn{5}{c|}{$\begin{array}{c}\text { Average structure of distribution of } \\
\text { indicators, \% }\end{array}$} \\
\cline { 2 - 6 } & \multicolumn{1}{|c|}{$\mathbf{1}$} & \multicolumn{1}{c|}{$\mathbf{2}$} & $\mathbf{3}$ & $\mathbf{4}$ & \multicolumn{1}{c|}{$\mathbf{5}$} \\
\hline Total & 100.00 & 100.00 & 100.00 & 100.00 & 100.00 \\
\hline m. Kyiv & 42.02 & 49.69 & 39.71 & 27.50 & 28.02 \\
\hline Kharkiv region & 17.58 & 7.94 & 15.98 & 15.05 & 14.09 \\
\hline Dnipropetrovsk region & 9.19 & 6.02 & 5.16 & 6.60 & 7.60 \\
\hline Donetsk region & 4.69 & 7.64 & 5.98 & 6.75 & 7.10 \\
\hline Lviv region. & 3.09 & 3.74 & 3.71 & 6.44 & 3.98 \\
\hline Odessa region & 2.06 & 5.30 & 4.98 & 4.90 & 4.78 \\
\hline Lugansk region & 1.32 & 2.38 & 2.61 & 2.91 & 4.14 \\
\hline Zaporozhye region & 5.50 & 1.54 & 2.14 & 2.61 & 3.13 \\
\hline Mykolaiv region & 3.83 & 1.39 & 1.42 & 1.37 & 1.73 \\
\hline Zhytomyr region & 0.21 & 0.52 & 0.24 & 0.92 & 0.30 \\
\hline Ivano-Frankivsk region & 0.53 & 1.11 & 2.94 & 1.91 & 2.08 \\
\hline Kiev region & 1.93 & 2.51 & 1.34 & 0.62 & 1.10 \\
\hline Vinnitsa region & 0.52 & 0.96 & 0.94 & 2.04 & 4.80 \\
\hline Poltava region & 0.64 & 2.23 & 1.33 & 2.66 & 2.26 \\
\hline Sumy region & 1.37 & 0.87 & 2.12 & 2.12 & 1.16 \\
\hline Others & 5.52 & 6.15 & 9.40 & 15.61 & 13.73 \\
\hline
\end{tabular}

The average structure of the indicators, which are factors of activity of scientific and technical systems in Ukraine, by regions during 2000 - 2017 years is given in Table. 3. Calculations made by the authors.

TABLE III. THE AVERAGE STRUCTURE OF THE INDICATORS, WHICH ARE FACTORS OF INFLUENCE ON SCIENTIFIC AND SCIENTIFIC-TECHNICAL ACTIVITY IN UKRAINE BY REGIONS DURING 2000 - 2017 YEARS

\begin{tabular}{|c|c|c|c|c|c|c|}
\hline \multirow[t]{2}{*}{ Regions } & \multicolumn{6}{|c|}{$\begin{array}{l}\text { Average structure of distribution of } \\
\text { indicators, } \%\end{array}$} \\
\hline & 1 & 2 & 3 & 4 & 5 & 6 \\
\hline Total & 26.66 & 22.80 & 41.12 & 32.44 & 60.75 & 52.09 \\
\hline m. Kyiv & 15.71 & 6.93 & 16.25 & 11.60 & 14.30 & 16.51 \\
\hline Kharkiv region & 6.36 & 6.74 & 8.44 & 7.77 & 3.50 & 4.63 \\
\hline Dnipropetrovsk region & 4.71 & 5.63 & 4.90 & 5.63 & 2.87 & 3.24 \\
\hline Donetsk region & 6.38 & 5.42 & 4.47 & 5.42 & 5.22 & 6.46 \\
\hline Lviv region. & 4.77 & 5.34 & 3.09 & 5.34 & 3.52 & 3.46 \\
\hline Odessa region & 2.93 & 2.94 & 1.18 & 2.94 & 0.22 & 0.39 \\
\hline Lugansk region & 2.62 & 3.74 & 4.14 & 3.74 & 0.40 & 0.77 \\
\hline Zaporozhye region & 3.05 & 2.97 & 2.15 & 2.97 & 0.35 & 0.53 \\
\hline Mykolaiv region & 0.81 & 2.00 & 0.32 & 2.00 & 0.16 & 0.26 \\
\hline Zhytomyr region & 1.55 & 2.41 & 0.61 & 2.41 & 0.19 & 0.30 \\
\hline $\begin{array}{l}\text { Ivano-Frankivsk } \\
\text { region }\end{array}$ & 2.56 & 3.96 & 2.19 & 3.96 & 1.41 & 1.68 \\
\hline Kiev region & 1.89 & 2.45 & 0.70 & 2.45 & 0.28 & 0.48 \\
\hline Vinnitsa region & 1.92 & 3.19 & 0.93 & 3.19 & 0.68 & 1.13 \\
\hline Poltava region & 1.62 & 2.20 & 2.13 & 2.20 & 0.50 & 1.13 \\
\hline Sumy region & 16.47 & 21.28 & 7.39 & 5.92 & 5.64 & 6.94 \\
\hline Others & 26.66 & 22.80 & 41.12 & 32.44 & 60.75 & 52.09 \\
\hline
\end{tabular}

In the table 3 the notation is taken:

1 - number of scientific organizations;

2 - number of organizations of the sphere of engineering;

3 - number of employees of scientific organizations; 
4 - number of employees of the organizations of the sphere of engineering;

5 - number of doctors of sciences, who performing works;

6 - the number of candidates of science who performing works.

The average structure of the indicators characterizing the innovative activity of industrial enterprises of Ukraine by region during $2005-2017$ is given in the table. 4 . Calculations made by the authors.

TABLE IV. THE AVERAGE STRUCTURE OF INDICATORS CHARACTERIZING THE INNOVATIVE ACTIVITY OF INDUSTRIAL ENTERPRISES OF UKRAINE BY REGION DURING 2005 - 2017

\begin{tabular}{|l|l|l|l|l|l|l|l|l|}
\hline \multirow{2}{*}{ Regions } & \multicolumn{6}{|c|}{ Average structure of distribution of indicators, \% } \\
\cline { 2 - 10 } & $\mathbf{1}$ & $\mathbf{2}$ & $\mathbf{3}$ & $\mathbf{4}$ & $\mathbf{5}$ & $\mathbf{6}$ & $\mathbf{7}$ & $\mathbf{8}$ \\
\hline Total & 100.0 & 100.0 & 100.0 & 100.0 & 100.0 & 100.0 & 100.0 & 100.0 \\
\hline m. Kyiv & 11.16 & 15.16 & 23.49 & 16.62 & 13.00 & 8.71 & 3.13 & 12.08 \\
\hline Kharkiv region & 11.18 & 6.18 & 17.02 & 8.23 & 11.15 & 7.30 & 7.61 & 10.57 \\
\hline $\begin{array}{l}\text { Dnipropetrovs } \\
\text { k region }\end{array}$ & 5.61 & 17.44 & 4.11 & 4.62 & 4.94 & 7.97 & 8.99 & 6.00 \\
\hline Donetsk region & 4.79 & 14.80 & 3.55 & 4.78 & 4.72 & 15.78 & 22.03 & 6.41 \\
\hline Lviv region. & 6.76 & 2.17 & 3.05 & 6.57 & 6.17 & 2.28 & 0.70 & 5.72 \\
\hline Odessa region & 4.28 & 3.08 & 2.14 & 3.43 & 3.77 & 3.45 & 3.56 & 3.74 \\
\hline $\begin{array}{l}\text { Lugansk } \\
\text { region }\end{array}$ & 2.96 & 3.95 & 1.62 & 1.11 & 2.68 & 12.21 & 14.66 & 3.09 \\
\hline $\begin{array}{l}\text { Zaporozhye } \\
\text { region }\end{array}$ & 4.37 & 3.54 & 12.25 & 9.83 & 4.78 & 9.06 & 12.97 & 5.66 \\
\hline $\begin{array}{l}\text { Mykolaiv } \\
\text { region }\end{array}$ & 3.79 & 4.23 & 1.21 & 1.95 & 2.56 & 1.60 & 2.21 & 1.82 \\
\hline $\begin{array}{l}\text { Zhytomyr } \\
\text { region }\end{array}$ & 3.13 & 0.89 & 1.45 & 1.05 & 3.31 & 0.89 & 0.28 & 3.20 \\
\hline $\begin{array}{l}\text { Ivano- } \\
\text { Frankivsk } \\
\text { region }\end{array}$ & 4.92 & 4.23 & 1.82 & 4.23 & 4.81 & 1.56 & 1.00 & 3.66 \\
\hline Kiev region & 3.87 & 1.62 & 2.20 & 3.57 & 4.42 & 1.90 & 0.97 & 3.53 \\
\hline Vinnitsa region & 3.19 & 3.25 & 2.32 & 2.49 & 2.97 & 0.92 & 0.26 & 2.55 \\
\hline Poltava region & 3.02 & 1.68 & 1.93 & 3.63 & 3.28 & 8.56 & 3.55 & 4.62 \\
\hline Sumy region & 2.25 & 2.67 & 6.63 & 7.05 & 2.79 & 4.82 & 7.77 & 3.79 \\
\hline Others & 24.73 & 15.11 & 15.20 & 20.83 & 24.65 & 13.00 & 10.31 & 23.56 \\
\hline
\end{tabular}

In the table 4 the notation is taken:

1 - number of industrial enterprises engaged in innovation activity;

2 - amount of financing of innovative activity of industrial enterprises in actual prices;

3 - number of introduced new technological processes by industrial enterprises;

4 - number of new (innovative) types of products developed by industrial enterprises;

5 - the number of industrial enterprises that implemented innovative products;

6 - the value of the realized innovation products by the industrial enterprises in actual prices

7 - the cost of sales of innovative products of industrial enterprises outside Ukraine;

8 - the number of enterprises that sold innovative products outside Ukraine.

A visual overview of the above tables (Table 2-4) allows us to determine that the results of the activities of scientific and technical systems and factors influencing their scientific and technological activity have a clear domination in the city Kyiv and Kharkiv. At the same time, as regards the indicators that characterize the innovative activity of industrial enterprises, these regions also have leadership positions, but these positions are either less visible or leadership of other regions noticeably.

Quantifying the identity of regional structures of the studied indicators can be estimated by calculating the deviations by module for each region, and in the subsequent summing in all regions. A detailed this method is considered in [6]. Total deviations by modulus of the regional structure of the studied indicators are given in Table. 5. Calculations made by the authors.

TABLE V. TOTAL DEVIATIONS BY MODULUS OF THE REGIONAL STRUCTURE OF THE STUDIED INDICATORS

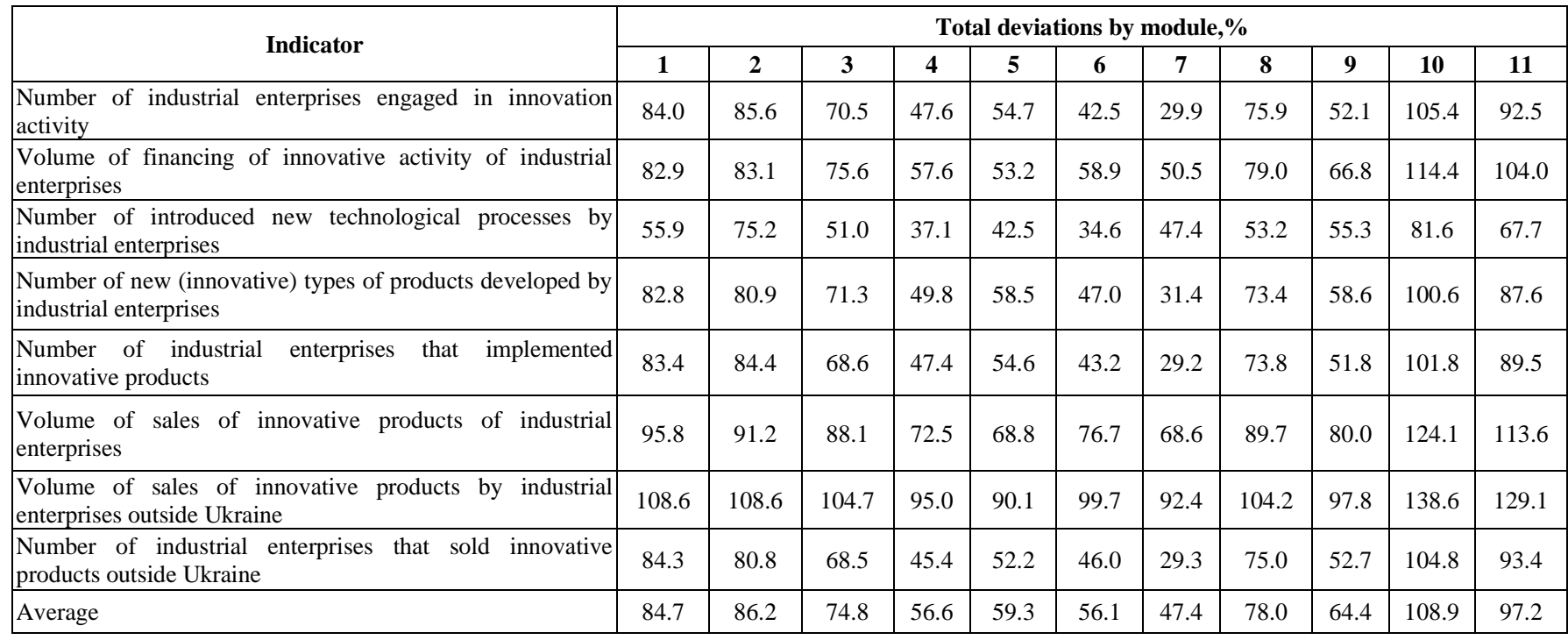


The columns have been accepted in the table 5:

1 - the volume of scientific works performed by scientific organizations in value measure;

2 - the volume of works by the organizations of the sphere of engineering in value measure;

3 - number of scientific works performed by scientific organizations;

4 - the number of printed works;

5 - the number of received security documents on intellectual property rights;

6 - number of scientific organizations;

7 - number of organizations of the sphere of engineering;

8 - number of employees of scientific organizations;

9 - number of employees of organizations of the sphere of engineering;

10 - number of doctors of science in the country;

11 - the number of candidates in the country.

Unfortunately, according to this method, there are no objective criteria for relation to a certain level of dependence: low, medium and high. The total deviation of $30 \%$ is considered subjectively as evidence of a high level of similarity of the regional structure. Consideration of data in Table 5 does not allow to quantify the similarity of regional structures of the studied indicators. Some similarity can be stated regarding the regional of structure of the organizations of the sphere of engineering and the regional structure of some indicators of innovation activity of industrial enterprises. Therefore, the regional concentration of organizations of the sphere of engineering is more in line with the regional concentration of innovation activities of industrial enterprises.

\section{DISCUSSION}

Considering the results of a comparison of the regional structure of the studied indicators, it should be clarified that such calculations the author have already been carried out in the period up to 2014, which was set out in [6]. In this work, a higher level of similarity of regional structures of the corresponding indicators was revealed. After 2014, this structure has changed, and this change is not related to the nature of the interconnection of scientific and technical systems in Ukraine and the innovation of activity of its industrial enterprises. Total changes in the corresponding structure reached $3-5 \%$ in the direction of the increase in deviation. While the results of the correlation analysis at the macro level of the interconnection of innovation activities of industrial enterprises and scientific and technical systems as before of 2014 and after - have not changed much.

The practical use of the method of comparing regional structures has shown that such studies yield more accurate results with the use of statistical data of a small period of time, for example 3-5 years. While a significant period of time, for example, 12 to 20 years, is required for correlation analysis. In practice, it is often not possible to compile statistical material for conducting a correlation analysis of regional processes for such a period in Ukraine for various reasons, for example, due to changes or cancellations of indicators.

Therefore, the correlation analysis based on the use of a relatively short period of time is appropriate to use in addition and along with the method of comparing the regional structure of indicators, which has proven itself better in the short-term period of time.

\section{CONCLUSION}

The results of the correlation analysis allowed the macro level to reveal the interconnection of the innovation activity of industrial enterprises in Ukraine with its scientific and technical systems. While the meso-use of the method of comparing regional structures by calculating deviations did not allow to reveal a significant link between the regional concentration of innovation activity and the regional concentration of all types of scientific and technical systems. The relevant relationship can be stated only with organizations of the sphere of engineering. In addition, a higher level of interconnection of innovation activities of industrial enterprises and organizations of the sphere of engineering also was revealed by the results of correlation analysis at the macro level. Clarification of the higher role of organizations of the sphere of engineering in the innovation activity of industrial enterprises in Ukraine allows us to revise and clarify priorities regarding the objects of influence in the state regulation in the direction. Practical use of the method of comparing regional structures of the studied indicators showed the feasibility of its use on the basis of statistical data of a small period of time (3 - 5 years) simultaneously with correlation analysis. The prospect of further research in the direction is a more detailed refinement of factors affecting the regional concentration of scientific and technical systems, as well as the development of new and more accurate methodological approaches to the study of cause and effect relationships in the activities these entities.

\section{References}

[1] I. Buzko, and R. Halhash, "Institutional model of strategic coordination of enterprises interaction in regional clusters", Herald Volodymyr Dahl East Ukrainian National University, no. 6(236), pp. 45-51, 2017.

[2] M.A. Demircioglu, and D.B. Audretsch, "Public sector innovation: the effect of universities", Journal of Technology Transfer, vol. 44 no. 2, pp. 596-614, 2019.

[3] R. Fudickar, and H. Hottenrott, "Public research and the innovation performance of new technology based firms", Journal of Technology Transfer, vol. 44, no.2, pp. 326-358, 2019.

[4] P. Hajek, R. Henriques, M. Castelli, and L. Vanneschi, "Forecasting performance of regional innovation systems using semantic-based genetic programming with local search optimizer", Computers and Operations Research, vol. 106, pp.179-190, 2019.

[5] Y. Klius, and V. Chizh, "Strategic analysis of the effective development of industrial enterprises on the basis of the use of "corporate innovation management chart", Baltic Journal of Economic Studies, vol. 3. no. 5. pp. 281 -288, 2017.

[6] I. Morhachov, Improvement of the state innovation policy of development of scientific and technical systems: monograph. Lugansk: Noulidg, 2014.

[7] D.C. Moura, M.J. Madeira, F.A.P. Duarte, J. Carvalho, and O. Kahilana. "Absorptive capacity and cooperation evidence in innovation from public policies for innovation", International Journal of Innovation Science, no.11(1), pp. 2-19, 2019.

[8] State Statistics Service of Ukraine. [Online]. Available: http://www.ukrstat.gov.ua. Accessed on: July 12, 2019.

[9] I. Semenenko, R. Halhash, and Y. Ivchenko, "Role of international organizations in promoting sustainable development in conflictaffected regions: case of Luhansk region in Ukraine", European Journal of Sustainable Development, vol. 8, no 2. pp. 21-34, 2019. 